UDC 620.197

\title{
CORROSION-ELECTROCHEMICAL BEHAVIOR OF POWDER STEEL O9G2S IN SULFURIC SOLUTIONS
}

\author{
H.M. Tahirli ${ }^{1}$, T.İ. Shirinov², A.T. Mammadov², M.Ch. Huseynov², \\ D.H. Baxishova ${ }^{1}$ \\ ${ }^{1}$ M. Nagiyev Institute of Catalysis and Inorganic Chemistry \\ National Academy of Sciences of Azerbaijan \\ H.Javid ave., 113, Baku AZ 1143, Azerbaijan Republic; e-mail: hitahirli@gmail.com \\ Azerbaycan Technical University \\ 25, Huseyn Javid ave., Baku
}

Received 12.08.2020

Accepted 29.09.2020

\begin{abstract}
By the method of polarization measurements there have been investigated the corrosionelectrochemical properties of steel 09G2S which was obtained by means of the powder metallurgy. Similar measurements were carried out for compact steel in order to compare the obtained data. Anodic and cathodic curves taken in the sea water showed that corrosion-electrochemical properties of both steels were identical, i.e. both cathodic and anodic processes on these steel samples proceed according to the same mechanism with the only difference that currents observed on the powder electrode are almost 2.5 times up from those on the compact electrode. It revealed that the corrosion rate of powder steel is also up 2.5 times from that on the compact steel. Corrosion-electrochemical studies into sulfate solutions with different $p H$ values showed that as $\mathrm{pH}$ increases, the stationary potentials of steels shifts to the negative side while rates of cathodic and anodic processes decrease. To our thinking, the transition regions on anodic curves result from the competing adsorption between $\mathrm{OH}^{-}$and $\mathrm{SO}_{4}^{2-}$ ions. The higher dissolution rates of the powder electrode in the investigated solutions are, on the one hand, due to high true surface of the powder steel and to non-equipotentiality of surface specified steel, on the other hand.
\end{abstract}

Keywords: corrosion-electrochemical studies, steel, the powder metallurgy anodic and cathodic curves, adsorption, corrosion rate, non-equipotentiality of surface

DOI: $10.32737 / 2221-8688-2020-3-403-409$

\section{Introduction}

The widespread application of iron-based powder materials in various areas of the national economy is suppressed by their low corrosion resistance when operating these wares in aggressive environment. The relatively high corrosion rate of powder products is mainly conditioned by their porosity, which promotes the destruction of the crystallites that make up individual fragments of the material. In all probability, the reason lies in electrode potentials, which are established inside the pores and sometimes significantly differ from the potential established on the electrode surface. The theory of porous electrodes is described in detail in reviews [1-3], and the practice in the works by N.D. Tomashov [4,5] and his collaborates, for example, ceramic titanium. In his later works on the corrosion properties of porous materials, the influence of various additives and the processing conditions of the corrosion loss of products are mainly discussed [6,7]. In all these works, the main attention is paid to the pretreatment of powder materials, such as the pressing pressure, annealing temperature, powders size, etc. [8,9]. Corrosion and especially electrochemical studies, as well as the composition of the aggressive environment, received little attention. Therefore, we needed in conducting studies mentioned above and, to the extent possible, find out causes of accelerated corrosion of these materials and propose methods for protecting powder products. The technology and methods of protection of powders obtained against metals and alloys are described in detail in a fundamental work by V.N. Antsiferov et al. [10]. 
Therefore, these methods are not referred to in this work; we just note that the steel powder we used was obtained by the spraying method. As a porous material there was used steel 09G2S, which is widely used as main constructional material in the wide hydraulic engineering structures. The use of this low alloy steel and its various modifications is due to the fact that at first, it allows to reduce the metal consumption of structures by an average of 16$20 \%$, and secondly, they have a very high technological effectiveness: they are well welded, characterized by the absence of brittleness at low temperatures, and the lack of corrosion resistance in atmospheric conditions as compared to carbon steels, as well as the lack of tendency to aging. The corrosion resistance of this steel, especially its powder products in the water media, has been understudied, and the available data are disparate in nature and mainly obtained in chloride media [6-8]. The corrosionelectrochemical properties of steel and its powders in electrolytes, as noted above, are of a different anionic composition, and all the more so in electrolytes with different acidities that have not been discussed in the literature. Therefore, the aim of the research was to illuminate roles of other anions, for example $\mathrm{SO}_{4}{ }^{-2}$ ions existing in significant amount in seawater and comparable to chlorine ions $\left(\mathrm{C}_{\mathrm{Cl}}-\right.$ $\left.=41.67 \% \mathrm{C}_{\mathrm{SO}_{4}^{2-}}=23.82 \%\right)[11]$.

\section{Methods of an experiment}

The corrosion-electrochemical properties of powder and compact steel 09G2S were studied through the use of ПИ-50-1 potentiostat with a ПР-8 programmer in a three-electrode glass cell which made it possible to conduct experiments at a controlled temperature, i.e. it had a water shirt. The cell temperature was maintained using a U-3 thermostat.

Electrodes for electrochemical studies were made of powder $(\mathrm{d}=100 \mu \mathrm{m})$ of $09 \mathrm{G} 2 \mathrm{~S}$ steel, pressed under $1000 \mathrm{MPa}$, and then subjected to heat treatment at a temperature of $t$ $=500{ }^{\circ} \mathrm{C}$. A silver chloride reference electrode was used as a reference electrode, and a wire was used as an auxiliary Pt wire. Quasipotentiostatic polarization cathode and anode curves were taken at a potential sweep rate of 12 $\mathrm{mV} / \mathrm{min}$.

Powdered metallurgy steel sample and compact samples were first mechanically treated to remove corrosion products, then grounded and polished with sandpaper of various grain sizes, degreased with ethyl alcohol, and rinsed with distilled water, then dried in desiccators. Solutions taken for electrochemical analysis were prepared through dissolving sulfuric acid and sodium- sulphate with laboratory reagent grade in distilled water. Electrolytes with different $\mathrm{pH}$ values were prepared by adding concentrated sulfuric acid in $1 \mathrm{M} \mathrm{Na}_{2} \mathrm{SO}_{4}$. In this case, the ionic strength of the solutions was kept constant.

\section{Experimental results and their discussion}

As noted above, the low-alloy steel 09G2S used by us is widely used in marine, hydraulic engineering structures. Therefore, it would be advisable to investigate the corrosionelectrochemical behavior of a powder electrode made of this steel in sea-water. The removal polarization curves on 09G2S steel are shown in Fig. 1. As can be seen, the shape of the curves on both steels is identical while the aging of athodic and anodic processes is significantly different, i.e. the cathodic oxygen reduction rate on the powder electrode at a potential of $0.75 \mathrm{~V}$ is approximately up 2.5 times from the compact electrode. A similar correlation is also observed in the anode section of the polarization curves. Corrosion rates calculated by the well-known method also differ by 2.5 times, i.e. $1.2 \cdot 10^{-5} \mathrm{~A}$ $/ \mathrm{cm}^{2}$ for a compact, and $3 \cdot 10^{-5} \mathrm{~A} / \mathrm{cm}^{2}$ for a powder electrode. All these data indicate that in neutral solutions the rate steel dissolution occurs according to the same mechanism, and the corrosion rate is limited by the rate of reduction of molecular oxygen. 


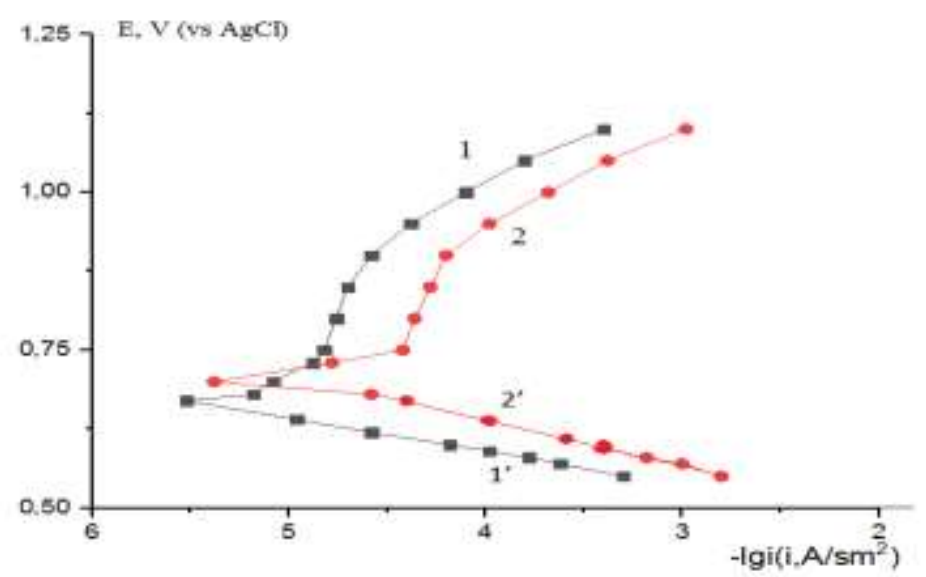

Fig. 1. Anodic $\left(1,2^{\prime}\right)$ and cathodic $(1,2)$ polarization curves of compact $\left(1,1^{\prime}\right)$ and powder steel $\left(2,2^{\prime}\right) 09 Г 2 \mathrm{C}$ in sea-water $\mathrm{t}=25^{\circ} \mathrm{C}$.

Products made by powder metallurgy can be used in different $\mathrm{pH}$ values environment. The corrosion rate of structural metals, including iron and its alloys, as well as their polarization characteristics, strongly depends on the $\mathrm{pH}$ of the medium. This is evidenced by the numerous works of researchers dealing with problems of corrosion and electrochemistry of metals $[11,12]$. Therefore, it would be advisable to study the effect of electrolyte $\mathrm{pH}$ on the polarization characteristics of the steel. Fig. 2 shows the anodic and cathodic polarization curves on compact steel 09G2S.

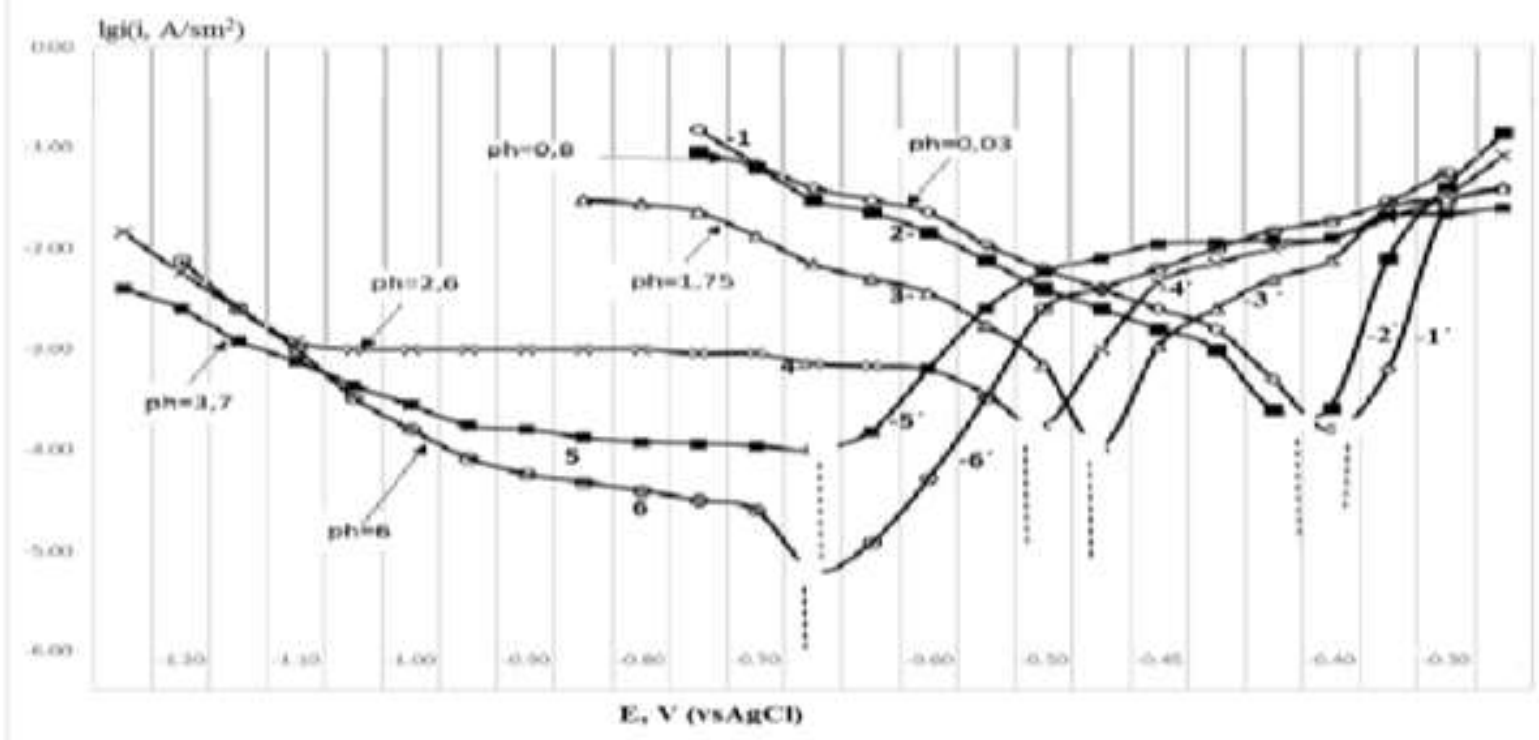

Fig. 2. Anodic $\left(1^{\prime} \div 6^{\prime}\right)$ and cathodic $(1 \div 6)$ polarization curves of $09 \mathrm{G} 2 \mathrm{~S}$ compact steel in sulfate solutions $\left(\mathrm{Na}_{2} \mathrm{SO}_{4}+\mathrm{H}_{2} \mathrm{SO}_{4}\right)$ with different $\mathrm{pH}$ values: $1.1^{\prime}-0.03 ; 2.2^{\prime}-0.8 ; 3.3-1.75 ; 4.4$-3.6 ; 5.5'-4.65; 6.6'$6.05 C_{\Sigma}=1 \mathrm{M} ; \mathrm{t}=25^{\circ} \mathrm{C}$. The dot line corresponds to the value of stationary potential.

Similar curves are illustrated in Fig. 3 for a powder electrode. As is seen from the figures presented, as $\mathrm{pH}$ increases the stationary potentials of the electrode move towards negative side. There were observed linear sections at the cathodic curves where $\mathrm{pH}$ values of solutions were low to demonstrate that cathodic processes proceed with the presence of hydrogenous particles. These particles are water molecules and $\mathrm{H}^{+}$ions in the electrolyte. Some curvature of the cathodic curves in the region of more cathodic potentials is probably due to the 
IR potential drop which is typical at higher current densities. At higher $\mathrm{pH}$ values (Fig. 2. the region of potentials of molecular oxygen curve 5.6) reduction is observed on cathode curves following which the process of cathodic hydrogen evolution begins.

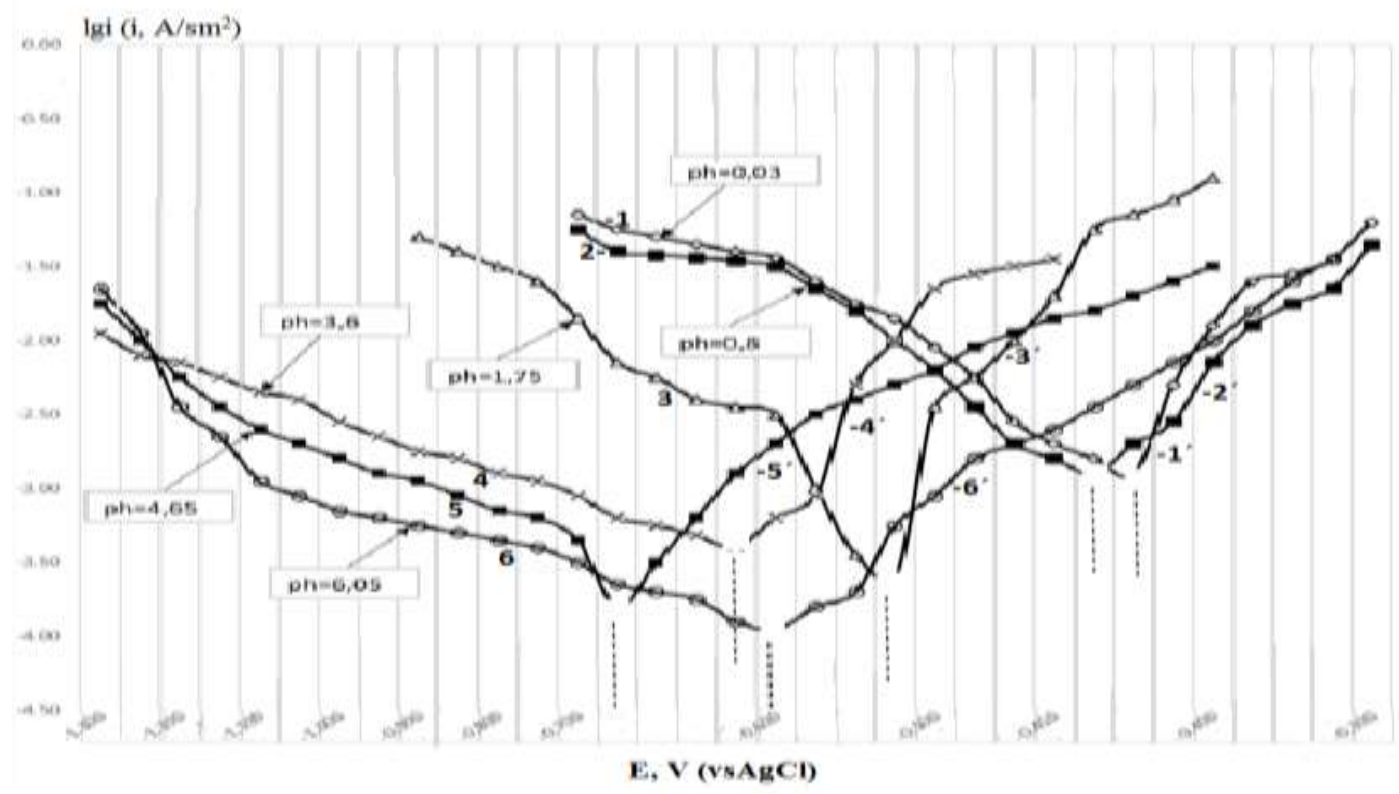

Fig. 3 Anodic $\left(1^{\prime} \div 6^{\prime}\right)$ and cathodic $(1 \div 6)$ polarization curves of 09G2S powder steel in sulfate solutions $\left(\mathrm{Na}_{2} \mathrm{SO}_{4}+\mathrm{H}_{2} \mathrm{SO}_{4}\right)$ with different $\mathrm{pH}$ values: $1.1^{\prime}-0.03$; 2.2'-0.8; 3.3'-1.75; 4.4'-2.6; 5.5 -3.7; 6.6-6.0 $C_{\Sigma}=$ $1 \mathrm{M} ; \mathrm{t}=25^{\circ} \mathrm{C}$. The dot line corresponds to the value of stationary potential.

On the anode curves taken in acidic solutions (cur. $1^{\prime} .2^{\prime} .3^{\prime} .4^{\prime}$ ) linear sections are observed corresponding to the anodic dissolution of steel. Deviation from the linear E-lgi dependence is observed at higher current densities. Perhaps, it is due to the IR drop in potential or the deceleration of the process of diverting the dissolution products into the depth of the solution. These processes are equally probable, since the experiments were carried out under stationary diffusion conditions. At relatively high $\mathrm{pH}$ (cr. 5' 6', 7'), where lower dissolution current densities are observed, electrolyte anions $\left(\mathrm{OH}^{-}, \mathrm{SO}_{4}{ }^{2-}\right)$, owing to the possible competition for adsorption sites on the surface, reduce the dissolution rate of the alloy.

Further displacement of the potential to the anode side due to the intensification of competing adsorption, one of the components displaces the other from the surface and, adsorbing on the metal, imposes its dissolution mechanism on the metal, i.e. in this case, it increases the anodic dissolution current.

According to Kolotyrkin [13], in terms of competitive adsorption, a particle promotes dissolution if, on the one hand, it is strongly adsorbed on the surface, and on the other hand, it should not lose its bond with solvent. Only in this state the adsorbed particle is capable of breaking off metallic atoms from crystalline lattice.

With strong adsorption, the anion loses its bond with the solution and forms a chemisorption film and remains on the surface. If the bond of the adsorbed particle with the surface is weak, it loses its bond with the surface as a result of thermal motion and leaves the surface. In our opinion, in this case $\left(\mathrm{SO}_{4}{ }^{2-}\right)$ ions displace $\left(\mathrm{OH}^{-}\right)$ ions from the surface and concurrently retain the bond with the solvent promoting accelerated dissolution of the metal.

Similar polarization curves recorded on a powder electrode are significantly higher than on a compact electrode; these currents are approximately an order of magnitude (in some cases even 1.5 orders of magnitude) higher than the currents shown in Fig. 2. The laws of electrochemical processes on a powder 
electrode are identical to the laws of electrochemical processes on a compact electrode. In this case, as the $\mathrm{pH}$ of the electrolyte rises, the stationary potential of the electrode shifts to the negative side, but there are some differences. On the cathode curves (1$6)$, especially on curves (4-6), the region of cathodic reduction of molecular oxygen is relatively longer than on the compact electrode. In our view, the desorption of oxygen electroreduction products occurs with a certain resistance in the pores of the electrode, which, in turn, slows down the process of adsorption of $\mathrm{H}^{+}$ions in the pores thereby reducing the rate of molecular hydrogen evolution. On the anode curves $\left(1^{\prime}-6^{\prime}\right)$ in acidic solutions, the linear Tafel section has a certain value, so the deviation from linearity occurs only at high currents, which is possibly related, as noted above, by IR to a drop in the potential and the slowness of removal of dissolution products deep into the solution. The two linear regions on the anode curves $5^{\prime}$ and $6^{\prime}$ are probably the result of competing adsorption between $\mathrm{OH}^{-}$and $\mathrm{SO}_{4}{ }^{2-}$ ions. In the transition region of potentials, competition for adsorption sites on the surface intensifies, that's why a certain delay is observed on the anode curve to violate the Tafel dependence $[12,14]$.

Fig.4 shows the dependence of the stationary potential of steels on the $\mathrm{pH}$ of sulfate electrolyte. As can be seen from Fig. 4, as pH increases, the solution of Est shifts toward the negative direction, and Est.-pH is linear. In our opinion, some scatter in the data observed for the powder electrode is related to the porosity of the steel electrode.

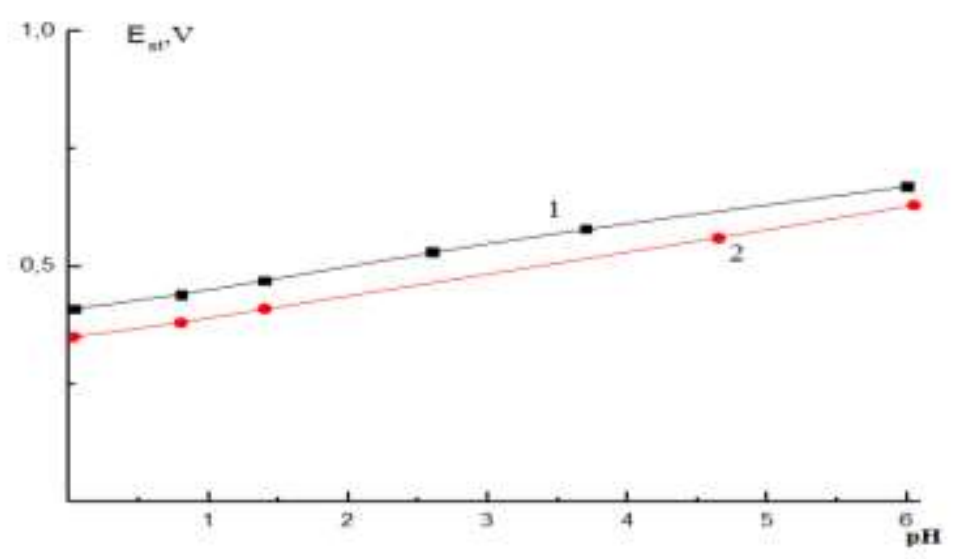

Fig. 4 Dependence of corrosion potential of compact (1) and powder (2) steel on the pH of sulfate solutions.

Thus, the method of electrochemical measurements was used to study the corrosion electrochemical behavior of $35 \mathrm{GS}$ powder steel in sulfate solutions. Electrochemical measurements into sulfate solutions with different $\mathrm{pH}$ values showed that as $\mathrm{pH}$ increases, the stationary potentials of steels shifts to the negative side while rates of cathodic and anodic processes decrease.
Moreover, in comparison with a compact alloy, powder steel dissolves at a higher speed, calculated per unit geometric area. The reason of such a behavior of the powder alloy is explained as being due to the non-equipotential surface, since the potential of the alloy pores sometimes significantly differs from the potential recorded on the surface.

\section{References}

1. Chizmadzhev Yu.A., Chirkov Yu.G. Porous electrodes. In the book, kinetics of complex electrochemical reactions. Moscow, ed. "Science", 1981, pp. 240-305.
2. Scheidegger A.E. The physics of flow through porous media. New YorkMcMillan 1961, 403p. 
3. Collins R.E. Flow of fluids through porous materials. New York: Reinhold, 1961,157p.

4. Tomashov N.D., Chernova G.P., Mansky Ch.G. Electrochemical behavior of cermet titanium. Protection of metals, 1974, no. 1, pp. 22-27.

5. Tomashov N.D., Chernova G.P., Mansky Ch.G. Electrochemical and corrosion properties of cermet alloys of titanium with palladium in hydrochloric acid solutions. Protection of metals, 1974, no. 6, pp. 643647.

6. Kichigin V.N., Bezmaterny N.V., Kichigina N.A., Koscheev O.P., Perelman O.M., Rabinovich A.I. Corrosion of some materials obtained by powder metallurgy in a solution of sodium chloride. Materials Corrosion and Protection. 2004, no. 11, pp. 5-9.

7. Burdikova T.V., Abdullin I.Sh., Shaekhov M.F., Evsyukova O.V., Vinokurov Yu.V. The effect of modifications of iron powders and materials based on them on corrosion resistance in aggressive environments. Bulletin of Kazan Technological University, 2004, pp. 266-275 (In Russian).

8. Kichigin V.Y., Perelman O. M., Rabinovich A.Y., Bezmaternykh N.V. and Koshcheev O.P. Determination of the corrosion rate of Powder Materials by Electrochemical metods. Protection of metals and Physical chemistry of Surfaces, 2011, vol. 47, no. 7, pp. 921-925.

9. Mahdi Dehestani, Kevin Trumble, Han Wang, Lia A. Stanciu Effects of microstructure and heat treatment on mechanical propertis and corrosion behavior of powder metallurgy derived Fe$30 \mathrm{Mn}$ alloy. Materials science and Engineering. 2017, vol. 703, pp. 214-226.

10. Antsiferov V.N., Bobrov G.V. et al. Powder metallurgy and sprayed coatings. Moscow: Metallurgy Publ., 1987, 729p.

11. Keshe G. Corrosion of metals. Moscow: Metallurgy Publ., 1984, pp. 121-133.

12. Florianovich G.M. The mechanism of active dissolution of metals of the iron group. In the book. Results of science and technology Corrosion and corrosion protection. T 6. Moscow: VINITI, 1978, pp. 136-179.

13. Kolotyrkin Y.M. On Sat Corrosion of chemical equipment. Moscow: MIHM, 1975, pp. 5-15.

14. Mamedov Sh.N., Tagirli G.M., Shirinov T.I., Mamedov A.T., Verdiev S.Ch. Anodic dissolution of reinforcing steels $35 \Gamma \mathrm{C}$ and AT-400C in mixed sulfate-chloride solutions. Chemical problems. 2015, no. 4, pp. 66-69.

\title{
09Г2C POLADININ SULFAT MӘHLULARINDA KORROZIYA-ELEKTROKIMMYӘVİ XASSӘLӘRI
}

\author{
H.M. Tahirli' ${ }^{1}$, T.İ. Şirinov ${ }^{2}$, A.T. Məmmədov ${ }^{2}$, M.Ç. Hüseynov ${ }^{2}$, D.H. Baxışova ${ }^{1}$ \\ ${ }^{1}$ AMEA-nın akad. M.Nă̆ıyev adına Kataliz və Qeyri-üzvi Kimya Institutu \\ AZ 1143, Bakl, H.Cavid pr., 113; e-mail: hitahirli@gmail.com \\ ${ }^{2}$ Azarbaycan Texniki Universiteti \\ AZ 1143, Bakı, H.Cavid pr., 25
}

Ovuntu metallurgiyası üsulu ilə alınmış 09Г2C çeşidli poladın korroziya-elektrokimyəvi xassələri polyarlaşma metodu ilə tədqiq olunmuşdur. Analoji ölçmələr alınan məlumatların müqayisəsi üçün kompakt polad üzərində də aparılmışdır. Dəniz suyu mühitində çəkilmiş anod və katod əyriləri hər iki növ poladın korroziya-elektrokimyəvi xassələrinin eyni olduğunu göstərməklə, hər iki elektrokimyəvi prosesin eyni mexanizmlə baş verdiyini aşkar etmişdir. Fərq yalnış ondan ibarət olmuşdur ki,ovuntu poladı üzərində müşahidə olunan cərəyan sıxlığı digərindən 2.5 dəfə böyük olmuşdur. Məlum olmuşdur ki, ovuntu poladının korroziya sürəti də 2.5 dəfə kompakt poladın korroziya sürətindən yüksəkdir. Müxtəlif $\mathrm{pH}-\mathrm{l}_{1}$ sulfat məhlullarında aparılan korroziyaelektrokimyəvi tədqiqatlar, məhlulun $\mathrm{pH}$-nın artması ilə poladların stasionar potensiallarının mənfi 
tərəfə sürüşdüyünü, katod və anod proseslərinin sürətlərinin kiçilməsini göstərmişdir. Anod əyriləri üzərində müşahidə olunan keçid oblastlar $\mathrm{OH}^{-}$və $\mathrm{SO}_{4}^{-2}$ ionlarının rəqabətli adsorbsiyasının nəticəsi kimi şərh olunmuşdur. Tədqiq olunan məhlullarda ovuntu poladının daha yüksək sürətlə həll olması bir tərəfdən ovuntu poladının həqiqi səthinin daha böyük olması, digər tərəfdən isə onun səthində elektrod potensialının qeyri-bərabər paylanması ilə izah olunmuşdur.

Açar sözlər: korroziya-elektrokimyəvi tədqiqatlar, anod və katod əyriləri, polad, ovuntu metallurgiyası üsulu, korroziya sürəti

\title{
КОРРОЗИОННО-ЭЛЕКТРОХИМИЧЕСКОЕ ПОВЕДЕНИЕ ПОРОШКОВОЙ СТАЛИ 09Г2С В СЕРНЫХ РАСТВОРАХ
}

\author{
Г.М. Тагирли ${ }^{1}$, Т.И. Ширинов ${ }^{2}$, А.Т. Маммедов ${ }^{2}$, М.Ш. Гусейнов ${ }^{2}$, \\ Д.Г. Бахышова ${ }^{1}$ \\ ${ }^{1}$ Институт катализа и неорганической химии им. акад. М.Нагиева \\ Начиональной АН Азербайджана \\ AZ 1143 Баку, пр.Г.Джавида, 113; e-mail: hitahirli@gmail.com \\ ${ }^{2}$ Азербайджанский Технический Университет \\ AZ 1143, Баку, пр. Г.Джавида, 25
}

Методом поляризационных измерений были исследованы коррозионно-электрохимические свойства стали 09Г2С, полученной методом порошковой металлургии. Аналогичные измерения были проведены и для компактной стали с целью сравнения полученных данных. Анодные и катодные кривые, снятые в морской воде, показали, что коррозионноэлектрохимические свойства обеих сталей идентичны, т.е. катодные и анодные процессы, протекающие на этих образцах стали, происходят по одному и тому же механизму, разница лишь в том, что токи, наблюдаемые на порошковом электроде, почти в 2,5 раза выше, чем на компактном электроде. Выявлено, что скорость коррозии порошковой стали также в 2.5 раза выше, чем на компактной стали. Коррозионно-электрохимические исследования, проведенные в сульфатных растворах с различными значениями $\mathrm{pH}$, показали, что с увеличением $\mathrm{pH}$ стационарные потенциалы сталей смещаются в отрицательную сторону и скорости катодного и анодного процессов снижаются. Переходные области на анодных кривых, по-нашему мнению, являются результатом конкурирующей адсорбции между $\mathrm{OH}^{-}$и $\mathrm{SO}_{4}^{2-}$ ионами. Более высокие скорости растворения порошкового электрода в исследованных растворах связаны, с одной стороны высокой истинной поверхностью порошковой стали, с другой - неэквипотенциальностью поверхности указанной стали.

Ключевые слова: коррозионно-электрохимические свойства, сталь, анодные и катодные кривые, скорость коррозии, порошковая металлургия 